\title{
Lower Extremity Reconstruction Using Vastus Lateralis Myocutaneous Flap versus Anterolateral Thigh Fasciocutaneous Flap
}

\author{
Min Jae Lee, In Sik Yun, Dong Kyun Rah, Won Jai Lee \\ Department of Plastic and Reconstructive Surgery, Yonsei University College of Medicine, Seoul, Korea
}

Background The anterolateral thigh (ALT) perforator flap has become a popular option for treating soft tissue defects of lower extremity reconstruction and can be combined with a segment of the vastus lateralis muscle. We present a comparison of the use of the ALT fasciocutaneous (ALT-FC) and myocutaneous flaps.

Methods We retrospectively reviewed patients in whom free-tissue transfer was performed between 2005 and 2011 for the reconstruction of lower extremity soft-tissue defects. Twentyfour patients were divided into two groups: reconstruction using an ALT-FC flap (12 cases) and reconstruction using a vastus lateralis myocutaneous (VL-MC) flap (12 cases). Postoperative complications, functional results, cosmetic results, and donor-site morbidities were studied.

Results Complete flap survival was 100\% in both groups. A flap complication was noted in one case (marginal dehiscence) of the ALT-FC group, and no complications were noted in the VL-MC group. In both groups, one case of partial skin graft loss occurred the donor site, and debulking surgeries were needed for two cases. There were no significant differences in the mean scores for either functional or cosmetic outcomes in either group.

Conclusions The VL-MC flap is able to fill occasional dead space and has comparable survival rates to ALT-FC with minimal donor-site morbidity. Additionally, the VL-MC flap is easily elevated without myocutaneous perforator injury.

Keywords Free tissue flaps / Lower extremity / Quadriceps muscle
Correspondence: Won Jai Lee Department of Plastic and Reconstructive Surgery, Yonsei University College of Medicine, 50 Yonsei-ro, Seodaemun-gu, Seoul 120-749, Korea

Tel: $+82-2-2228-2210$

Fax: +82-2-361-6947

E-mail:pswjlee@yuhs.ac

Received: 12 Apr 2012 • Revised: 12 Jun 2012 • Accepted: 19 Jun 2012

pISSN: 2234-6163 • elSSN: 2234-6171 • http://dx.doi.org/10.5999/aps.2012.39.4.367• Arch Plast Surg 2012;39:367-375

\section{INTRODUCTION}

The value of free-tissue transfer has provided various options for defects of the lower extremities, allowing the preservation and maintenance of the functional and cosmetic status of the limb [1-4]. The anterolateral thigh (ALT) flap was first reported by Song et al. [5] in 1984, and has become a popular option for soft-tissue reconstruction because of the large amount of available skin, versatility, and minimal donor-site morbidity. In addi- tion, the thickness of the flap can be adjusted [6-8]. Therefore, the ALT flap has been used for head and neck, extremity, and trunk defect reconstructions. The ALT perforator flap is conventionally designed as a fasciocutaneous flap that is indicated whenever a relatively thin and large flap is required for reconstruction. Coverage of a tissue defect in the lower extremity, especially on the dorsum of the foot and the anterior aspect of the tibia, requires a thin and pliable flap. The ALT fasciocutaneous (ALT-FC) flap can be thinned uniformly, and excellent results 
can be obtained with a thin ALT flap, both functionally and cosmetically.

Occasionally, lower leg defects have exposed bone or muscle and sufficient tissue volume is needed to fill the defect. The ALT flap can be combined with a segment of the vastus lateralis muscle for the successful treatment of osteomyelitis, a large composite defect, or obliteration of dead spaces in the lower extremity [6]. Harvesting of the vastus lateralis myocutaneous (VL-MC) flap is easier and faster because dissection of the vastus lateralis pedicle is not needed and twisting of the pedicle is less likely to occur.

In this study, we compare the usefulness of the ALT-FC and VLMC (including a small cuff of the vastus lateralis muscle) flaps for lower extremity reconstruction in 24 patients.

\section{METHODS}

We retrospectively reviewed patients in whom free-tissue transfer was performed for the reconstruction of lower extremity softtissue defects between October 2005 and November 2011. 24 patients meeting this criterion were divided into two groups: reconstruction using an ALT-FC flap (12 cases) and reconstruction using a VL-MC flap (12 cases).

We reviewed each patient's medical records, including age, sex, defect site, flap survival, flap complication, donor site closure method, and morbidity.

To compare the two groups' results, two independent physicians graded the patients' functional and cosmetic outcomes using a 4-point scale: poor (score of 0 ), average (score of 1 ), good (score of 2), and excellent (score of 3 ), and all of the patients were questioned about the functional and cosmetic outcomes by questionnaires with the same grading system. We used the average score of the physicians' and patients' score. The patients walked in a 10 meter straight line, went up 12 steps, and put on their socks and shoes during every outpatient department visit, and we evaluated them in terms of functional outcomes. Preoperative evaluation was not performed, and we questioned the patients about the preoperative state by questionnaire (Table 1). Having no problem with these activities was assigned a score of 3, minor disability compared to the preoperative state (limp when they walked, hold banister when they went up the stairs, take half as much more time putting on socks and shoes than on the non-operated side) were assigned a score of 2 , major disability of these activities (resting when they walked or went up the stairs, taking more than one and a half times as long to put on socks and shoes than on the non-operated side) were assigned a score of 1 , impossibility of completing one of these activities were assigned a score of 0 . Additionally, the flap contour, color

\begin{tabular}{l} 
Table 1. Questionnaire given to patients for assessment of \\
their functional and cosmetic outcome \\
\hline Patient scale \\
Scale definition \\
0: poor (absolutely no), 1: average (no), 2: good (yes), 3: excellent \\
(absolutely yes) \\
Functional outcomes (preoperative state/postoperative state) \\
1. You can walk all round the school ground. \\
2. You can climb one more floor by stair. \\
3. You can put on your socks and shoes by yourself. \\
Cosmetic outcomes (postoperative state) \\
1. You are satisfied with shape where you had operation. \\
2. You are satisfied with skin color where you had operation. \\
3. What is your overall opinion for your operation site?
\end{tabular}

matching, and flap thickness were evaluated in terms of cosmetic outcomes.

\section{Surgical technique of the VL-MC flap}

A line is first drawn between the anterior superior iliac spine and the midpoint of the lateral border of the patella on the donor thigh with the patient in a supine position. Cutaneous perforators (either septocutaneous or musculocutaneous) are mapped using a portable Doppler, and the proper flap design is performed around the perforators. A medial incision of the flap is made, and the flap is then elevated subfascially.

In cases of myocutaneous type flap elevation, the intermuscular septum is explored and dissected between the rectus femoris and vastus lateralis muscles. The subfascial dissection is continued laterally until the descending branch of the lateral femoral circumflex artery is identified. Subsequently, vessels supplying the skin are traced and confirmed to determine their origins. Once this information is known, a myocutaneous flap can be confidently harvested by inclusion of the skin and the vastus lateralis muscle both proximal and distal to these perforators. This is the most reliable method because the myocutaneous flap includes either the septocutaneous or myocutaneous perforator and vastus lateralis muscle as needed, eliminating the need for intramuscular vessel dissection (Fig. 1).

The donor site was closed directly when the width of the flap was less than $10 \mathrm{~cm}$; larger defects required split-thickness skin grafts.

\section{Statistical methods}

We compared flap survival, flap complications, and donor-site morbidity using a chi-squared test, and function and cosmetic outcomes using a t-test. We used the SPSS ver. 18.0 (SPSS Inc., Chicago, IL, USA). Differences were considered statistically significant when the P-value was less than 0.05 . 


\section{Fig. 1. Flap harvesting procedure}

(A) Anatomy of the lateral thigh. The lateral femoral circumflex artery extends between the rectus femoris and vastus lateralis muscles. (B) Schematic representation of VL-MC flap elevation. The musculocutaneous perforator is included in the vastus lateralis muscle, so there is no need for intramuscular dissection. (C) Clinical photo of the VL-MC flap of a patient in the VL-MC group. (D) Clinical photo of the anterolateral thigh fasciocutaneous flap of a patient in the ALT-FC group. VL-MC, vastus lateralis myocutaneous; ALT-FC, anterolateral fasciocutaneous; RF, rectus femoris muscle; LFCA, descending branch of lateral femoral circumflex artery; VL, vastus lateralis; LFCN, lateral femoral cutaneous nerve; MP, musculocutaneous perforator; VI, vastus intermedius muscle.

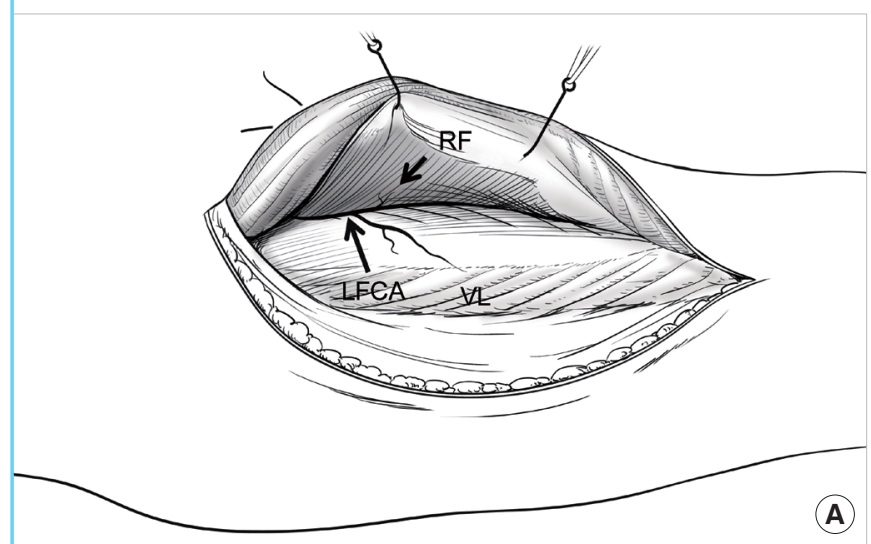

(A)

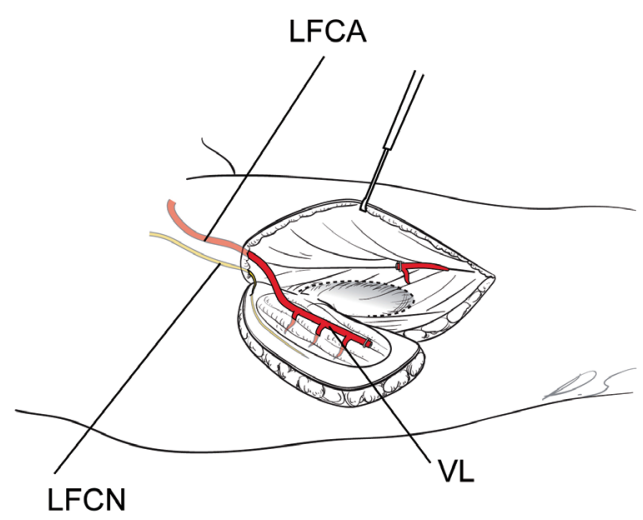

(B)
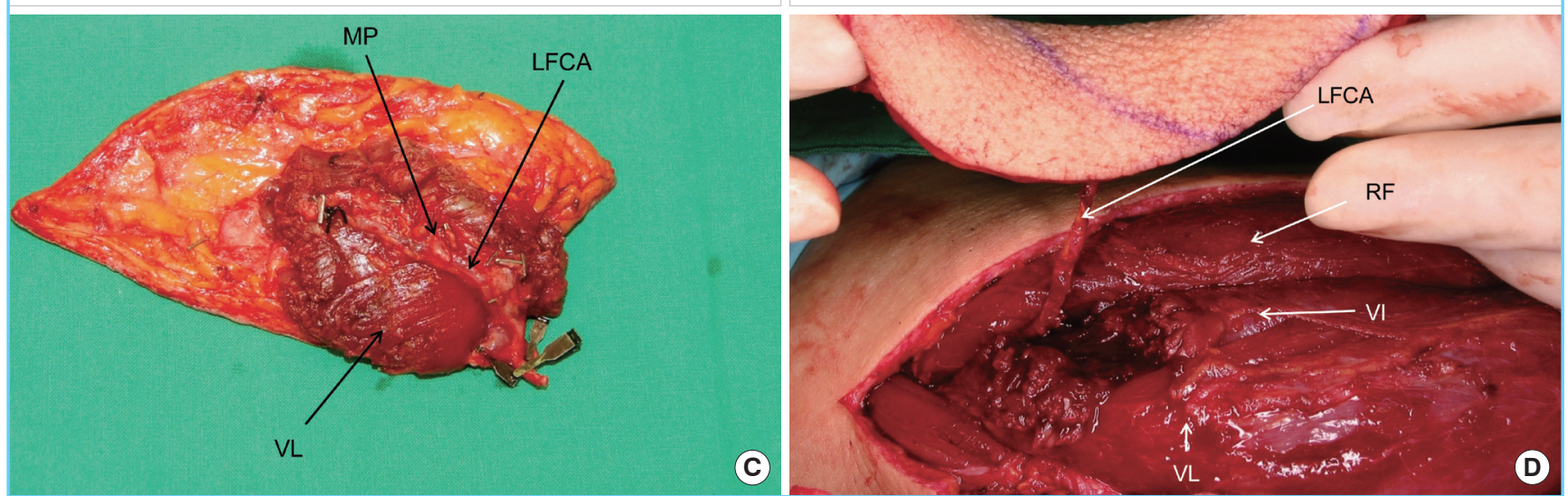

\section{RESUITS}

The defects of 24 patients were reconstructed using either an ALT-FC or VL-MC flap. There were 17 male and 7 female patients, and their ages ranged from 14 to 68 years, with a mean age of 46.7 years. The mean age of the VL-MC group (51.4 years) was greater than that of the ALT-FC group (41.9 years). Flap survival was 100 percent in both groups (Figs. 2-4). Among these 24 patients, 12 patients had acute or subacute wounds resulting from trauma, 3 patients had chronic ulcers resulting from diabetic mellitus or peripheral arterial occlusive disease, 3 patients had soft-tissue defects resulting from cancer, 2 patients had pressure sores, 3 patients had post-burn scar contractures, and 1 patient had a chronic osteoradionecrotic ulcer. The descending branch of the lateral femoral circumflex artery (in one case, the flap was harvested from the contralateral thigh), the posterior tibial artery (13 cases), and the anterior tibial artery (10 cases) were used as recipient vessels (Tables 2,3 ).
There were no significant differences in the mean scores for the functional and cosmetic outcomes in either group according to the evaluations made by two independent physicians and the patient questionnaire $(\mathrm{P}>0.05)$ (Table 4$)$. In the ALT-FC group, the average functional outcome score was 2.67, and the average cosmetic outcome score was 2.4. In the VL-MC group, the average functional outcome score was 2.65 , and the average cosmetic outcome score was 2.36 .

One case of flap dehiscence was noted on the flap margin in the ALT-FC group. However, the flap survived without dehiscence after a secondary repair.

Debulking procedures were performed for two patients in each group. The patients complained that it was difficult to put onshoes because of the bulky flap and that the flap contour was not aesthetically pleasing. After the debulking procedures, we achieved satisfactory results in terms of contour and functional outcome.

For donor site closure, we performed skin grafts in $25 \%$ (three 


\section{Fig. 2. Reconstruction of the posterior heel using an ALT-FC flap}

(A) A crushing injury to the heel. After debridement, a $3 \times 3 \mathrm{~cm}$ area of the calcaneal bone was exposed. The defect extended to both the subcutaneous and muscle layers. (B) An ALT-FC flap was transferred onto the defect. (C, D) Results 16 months after surgery. ALT-FC, anterolateral fasciocutaneous.

$$
\text { , }
$$
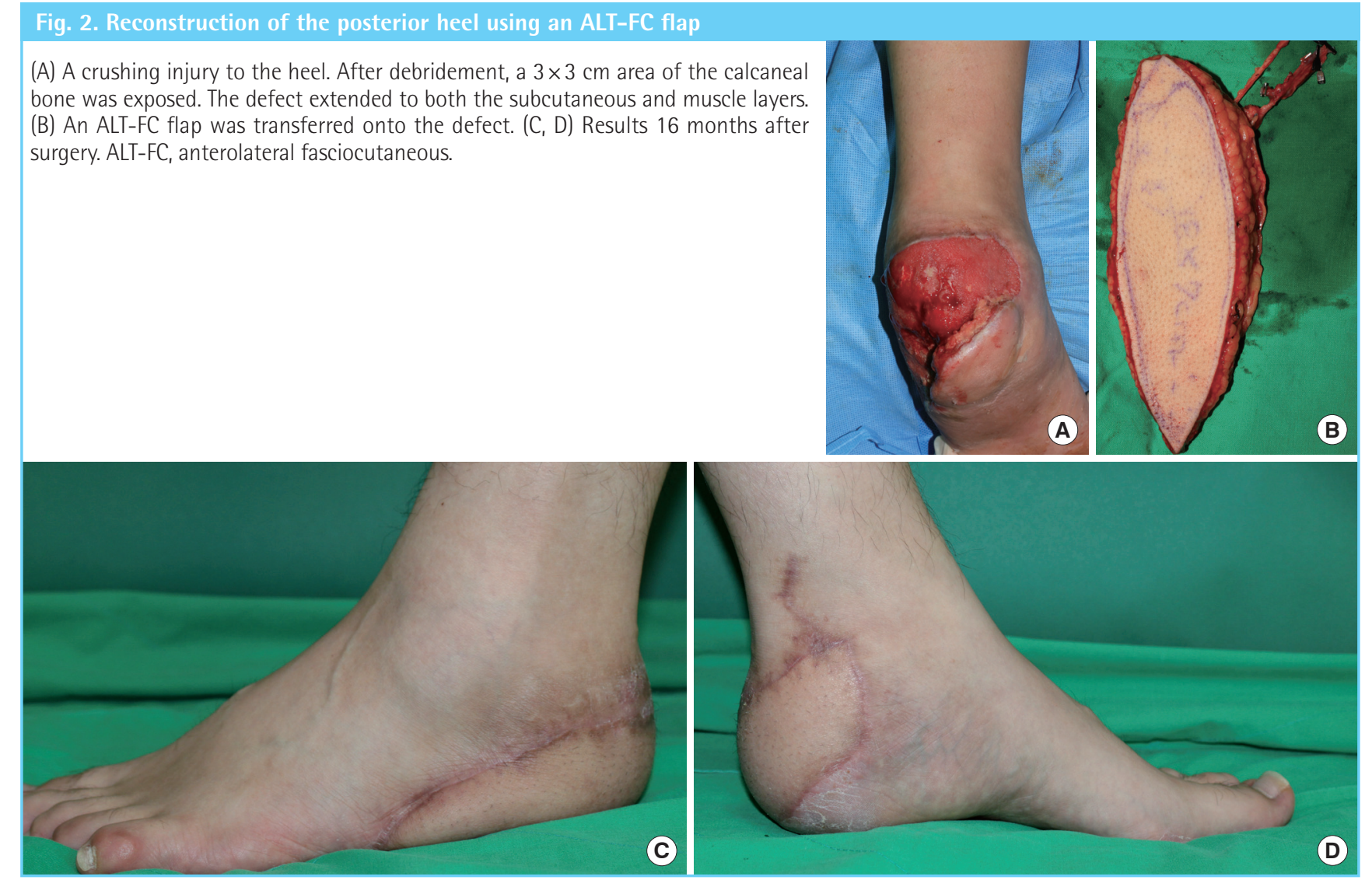

\section{Fig. 3. Reconstruction of the sole using a VL-MC flap}

(A) After wide excision of the invasive squamous cell carcinoma, a $7 \times 5 \mathrm{~cm}$ area of the calcaneal bone was exposed. (B) The VL-MC flap was elevated to cover the defect. (C, D) Results 24 months after surgery. VL-MC, vastus lateralis myocutaneous.
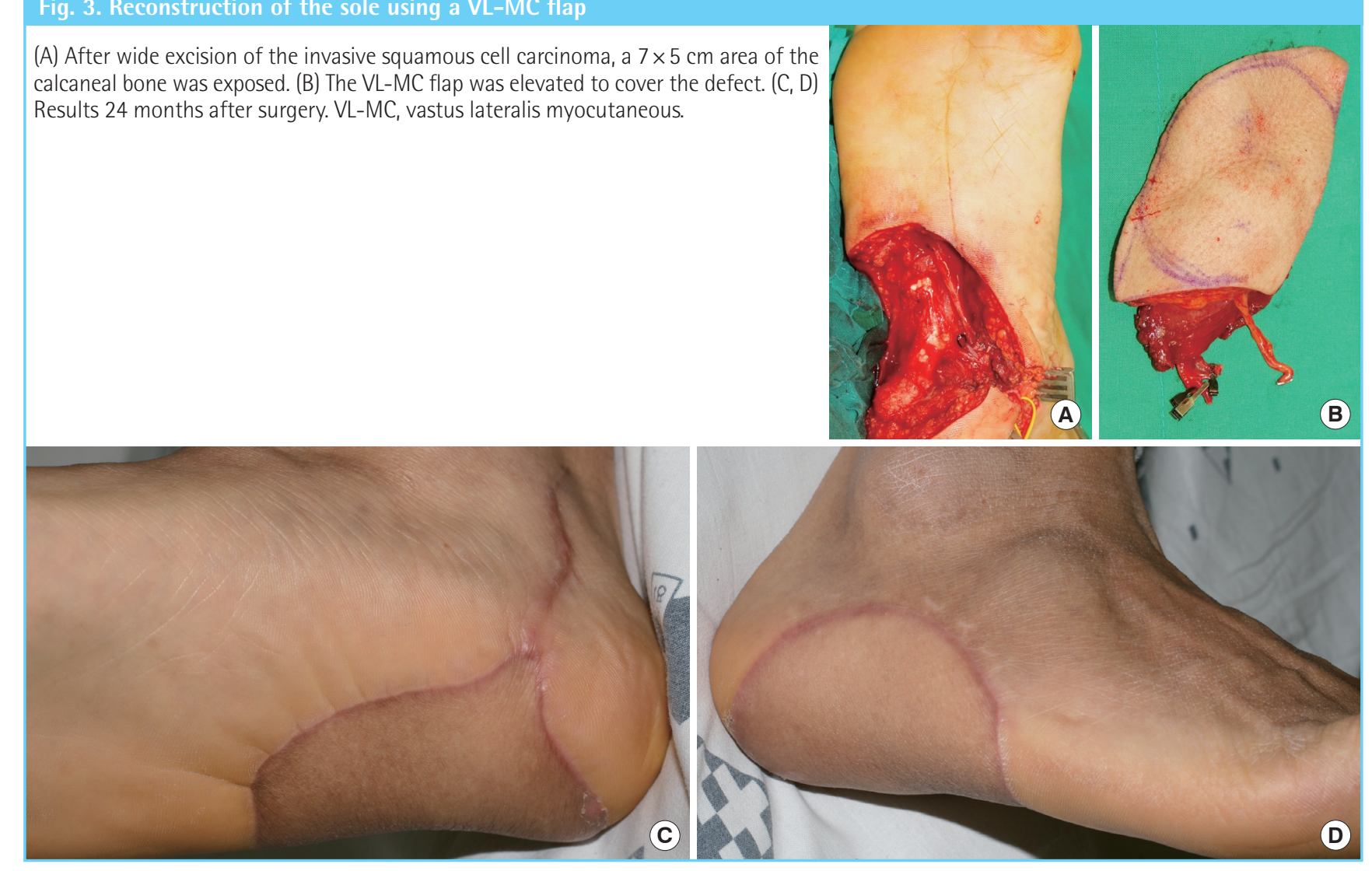


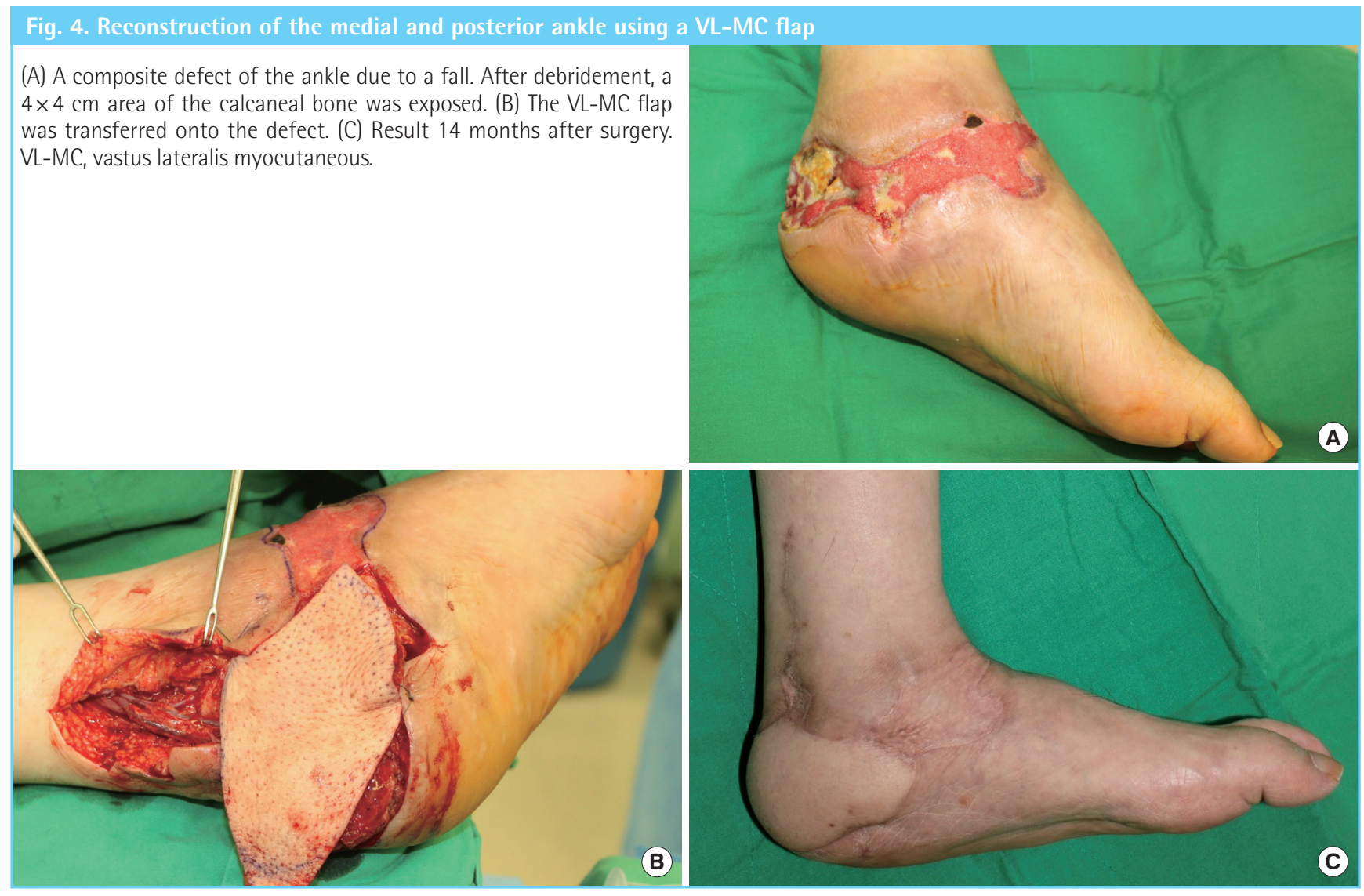

patients) of the cases in the ALT-FC group, and in 17\% (two patients) of the patients in the VL-MC group. We found neither complications nor deformities in the primary closure patient group, but partial skin graft loss occurred at the donor site in one case in both groups. We subsequently performed skin grafts at these skin graft loss sites, and all of the grafts were successful (Tables 2, 3). Postoperative follow-up periods were 2 to 31 months (average, 13.8 months). During the follow-up visits, no specific complications were noted, and the flaps were properly contoured with no gait disturbances.

\section{Case 1}

A 24-year-old man had a traffic accident that resulted in a crushing injury of the heel. The defect extended to the subcutaneous and muscle layers. After debridement of the wound, an $18 \times 7 \mathrm{~cm}$ ALT-FC flap was transferred onto the defect. The recipient vessel was the posterior tibial artery, and the lateral femoral cutaneous nerve was anastomosed with the cutaneous branch of the tibial nerve. The donor site underwent primary closure. Sixteen months after surgery, successful flap transfer provided good soft-tissue coverage and tolerable walking. The functional outcome score was 2.67, and the cosmetic outcome score was 3 (Fig. 2).

\section{Case 2}

A 62 -year-old male patient had a $5 \times 5 \mathrm{~cm}$ invasive squamous cell carcinoma of the heel pad. Wide excision with $2-\mathrm{cm}$ margins of the tumor was performed. After excision, a $7 \times 5 \mathrm{~cm}$ area of the calcaneus was exposed, requiring an adequate volume of tissue. We used a VL-MC flap to cover the defect. The donor site underwent primary closure. Twenty-four months after surgery, the flap survived completely with a good contour and function. The scores of both functional and cosmetic outcomes were 3 (Fig. 3).

\section{Case 3}

A 56-year-old male patient presented with a composite defect of the ankle due to a fall. After debridement, a $4 \times 4 \mathrm{~cm}$ area of the calcaneus was exposed. We used a VL-MC flap with sufficient volume to cover the defect. Fourteen months after surgery, the flap survived well with a good contour. The functional outcome score was 3, and the cosmetic outcome score was 2.67 (Fig. 4).

\section{DISCUSSION}

The treatment choice for soft-tissue defects of the lower extremity depends on the size and location of the wound. Proximal- 
Table 2. Patient demographics of ALT-FC group

\begin{tabular}{|c|c|c|c|c|c|c|c|c|c|c|c|c|c|}
\hline Patient & $\begin{array}{l}\text { Sex/ } \\
\text { Age } \\
\text { (yr) }\end{array}$ & Site & Cause & $\begin{array}{l}\text { Size of bone } \\
\text { or tendon } \\
\text { exposure } \\
\text { (cm) }\end{array}$ & $\begin{array}{l}\text { Size (F) } \\
(\mathrm{cm})\end{array}$ & $\begin{array}{l}\text { Recipient } \\
\text { vessel }\end{array}$ & $\begin{array}{l}\text { Com- } \\
\text { plications } \\
\text { (F) }\end{array}$ & $\begin{array}{l}\text { Deb- } \\
\text { ulking }\end{array}$ & $\begin{array}{l}\text { Donor } \\
\text { closure } \\
\text { method }\end{array}$ & $\begin{array}{l}\text { Com- } \\
\text { plica- } \\
\text { tions } \\
\text { (D) }\end{array}$ & $\begin{array}{c}\text { FO } \\
(0-3)\end{array}$ & $\begin{array}{c}\mathrm{CO} \\
(0-3)\end{array}$ & $\underset{(\mathrm{mo})}{\mathrm{FU}}$ \\
\hline 1 & $F / 59$ & Heel & $\begin{array}{l}\text { Postburn scar } \\
\text { contracture }\end{array}$ & $\begin{array}{c}\text { Calcaneous } \\
3 \times 2\end{array}$ & $10 \times 6$ & PTA & $\begin{array}{c}\text { Dehiscence } \\
(1 \times 1 \mathrm{~cm})\end{array}$ & No & $\begin{array}{l}\text { Primary } \\
\text { repair }\end{array}$ & None & 2.84 & 2.67 & 31 \\
\hline 2 & $\mathrm{~F} / 17$ & Heel & $\begin{array}{l}\text { Pressure } \\
\text { sore }\end{array}$ & $\begin{array}{c}\text { Calcaneous } \\
3 \times 3\end{array}$ & $10 \times 8$ & PTA & None & No & $\begin{array}{l}\text { Primary } \\
\text { repair }\end{array}$ & None & 2.84 & 1.83 & 9 \\
\hline 3 & $M / 24$ & Heel & Trauma & $\begin{array}{c}\text { Calcaneous } \\
3 \times 3\end{array}$ & $18 \times 7$ & PTA & None & No & $\begin{array}{l}\text { Primary } \\
\text { repair }\end{array}$ & None & 2.67 & 3 & 16 \\
\hline 4 & $\mathrm{M} / 43$ & 1st toe & $\begin{array}{l}\text { Cancer } \\
\text { excision }\end{array}$ & $\begin{array}{l}\text { 1st toe, } \\
\text { metatarsal } \\
\text { bone } 3 \times 1\end{array}$ & $10 \times 6$ & ATA & None & No & $\begin{array}{l}\text { Primary } \\
\text { repair }\end{array}$ & None & 2.5 & 2.67 & 3 \\
\hline 5 & $F / 56$ & Knee & $\begin{array}{c}\text { Osteora- } \\
\text { dionecrosis }\end{array}$ & $\begin{array}{l}\text { Patella } \\
4 \times 4\end{array}$ & $16 \times 10$ & LFCA & None & No & STSG & None & 2.34 & 1.84 & 26 \\
\hline 6 & $\mathrm{M} / 40$ & $\begin{array}{l}\text { Dorsum } \\
\text { of foot }\end{array}$ & $\begin{array}{l}\text { Chronic } \\
\text { ulcer }\end{array}$ & $\begin{array}{l}\text { Tendon } \\
\text { exposure }\end{array}$ & $10 \times 6$ & ATA & None & Yes & $\begin{array}{l}\text { Primary } \\
\text { repair }\end{array}$ & None & 2.67 & 2.5 & 28 \\
\hline 7 & $F / 33$ & Heel & $\begin{array}{l}\text { Pressure } \\
\text { sore }\end{array}$ & $\begin{array}{l}\text { Calcaneous } \\
2 \times 2\end{array}$ & $12 \times 6$ & PTA & None & No & $\begin{array}{l}\text { Primary } \\
\text { repair }\end{array}$ & None & 3 & 3 & 12 \\
\hline 8 & M/63 & $\begin{array}{l}\text { Heel, } \\
\text { sole }\end{array}$ & Trauma & $\begin{array}{l}\text { Calcaneous } \\
\text { plantar side } \\
4 \times 4 \text {, } \\
\text { calcaneous } \\
\text { tuberosity } \\
3 \times 3\end{array}$ & $\begin{array}{c}13 \times 8 \\
6 \times 6 \\
\text { (chimeric } \\
\text { flap) }\end{array}$ & PTA & None & No & STSG & $\begin{array}{c}\text { Partial loss } \\
(5 \times 5 \mathrm{~cm})\end{array}$ & 2.5 & 1.5 & 2 \\
\hline 9 & $\mathrm{M} / 51$ & Heel & Trauma & $\begin{array}{l}\text { Calcaneous } \\
\qquad 1 \times 1\end{array}$ & $10 \times 5$ & PTA & None & No & $\begin{array}{l}\text { Primary } \\
\text { repair }\end{array}$ & None & 2.34 & 2.67 & 2 \\
\hline 10 & $\mathrm{~F} / 17$ & $\begin{array}{l}\text { Dorsum } \\
\text { of foot }\end{array}$ & Trauma & $\begin{array}{c}\text { Metatarsal } \\
\text { bone } 3 \times 3 \text {, } \\
\text { tendon } \\
\text { exposure }\end{array}$ & $20 \times 10$ & ATA & None & Yes & STSG & None & 2.84 & 2.67 & 9 \\
\hline 12 & $\mathrm{M} / 45$ & $\begin{array}{l}\text { Dorsum } \\
\text { of foot }\end{array}$ & Trauma & $\begin{array}{l}\text { Metatarsal } \\
\text { bone } 2 \times 2 \text {, } \\
\text { tendon } \\
\text { exposure }\end{array}$ & $12 \times 5$ & ATA & None & No & $\begin{array}{l}\text { Primary } \\
\text { repair }\end{array}$ & None & 2.84 & 2.17 & 6 \\
\hline 13 & $\mathrm{~F} / 55$ & $\begin{array}{l}\text { Dorsum } \\
\text { of foot }\end{array}$ & $\begin{array}{l}\text { Postburn scar } \\
\text { contracture }\end{array}$ & $\begin{array}{l}\text { Tendon } \\
\text { exposure }\end{array}$ & $12 \times 7$ & ATA & None & No & $\begin{array}{l}\text { Primary } \\
\text { repair }\end{array}$ & None & 2.67 & 2.34 & 3 \\
\hline Mean & 41.92 & & & & & & & & & & 2.67 & 2.4 & 12.25 \\
\hline Rate (\%) & & & & & & & 8.33 & 16.67 & 25 & 8.33 & & & \\
\hline
\end{tabular}

third leg injuries can often be addressed by transposing a local muscle flap, such as the gastrocnemius and tibialis anterior muscles. In the middle third of the leg, the soleus muscle flap can be used for coverage. Reconstructions in distal-third leg wounds often have been accomplished using free tissue transfer [9].

Occasionally, a large dead space occurs, and sufficient bulk is required to fill this space in the lower extremity. When extensive soft-tissue loss occurs, the use of a local flap in wound closure is generally difficult. Advances in microsurgery have provided alternative reconstructive options [10].

ALT flaps have been used widely in head and neck, trunk, and extremity reconstruction, and can be customized as fasciocutaneous, adipofascial, or musculocutaneous flaps. We used either an ALT-FC or VL-MC flap for lower extremity reconstruction, de- pending on the size of the bone exposure and three-dimensional volume of the defect. An ALT-FC flap ican be used in cases where a thin flap is required, such as the dorsum of the foot or posterior aspect of the ankle. A VL-MC flap can be used for a large, boneexposed area ( $>4 \times 4 \mathrm{~cm}$ bone exposure) and weight-bearing area, such as the sole or heel pad.

The ALT flap is based on either the septocutaneous or musculocutaneous perforators of the descending branch of the lateral circumflex femoral artery [5]. Kimata et al. [11] reported that of 171 perforators, 31 (18.1\%) were septocutaneous and 140 (81.9\%) were musculocutaneous, and Choi et al. [12] reported that of 160 perforators, 28 (17.5\%) were septocutaneous perforators and $132(82.5 \%)$ were musculocutaenous perforators. In our cases, 6 (25\%) were septocutaneous perforators and 18 
Table 3. Patient demographics of VL-MC group

\begin{tabular}{|c|c|c|c|c|c|c|c|c|c|c|c|c|c|}
\hline Patient & $\begin{array}{l}\text { Sex/ } \\
\text { Age } \\
\text { (yr) }\end{array}$ & Site & Cause & $\begin{array}{l}\text { Size of bone } \\
\text { or tendon } \\
\text { exposure } \\
\text { (cm) }\end{array}$ & $\begin{array}{l}\text { Size }(F) \\
(\mathrm{cm})\end{array}$ & $\begin{array}{l}\text { Recipient } \\
\text { vessel }\end{array}$ & $\begin{array}{l}\text { Com- } \\
\text { plications } \\
\text { (F) }\end{array}$ & $\begin{array}{l}\text { Deb- } \\
\text { ulking }\end{array}$ & $\begin{array}{l}\text { Donor } \\
\text { closure } \\
\text { method }\end{array}$ & $\begin{array}{l}\text { Com- } \\
\text { plica- } \\
\text { tions } \\
\text { (D) }\end{array}$ & $\begin{array}{l}\text { FO } \\
(0-3)\end{array}$ & $\begin{array}{c}\text { Co } \\
(0-3)\end{array}$ & $\begin{array}{c}\text { FU } \\
(\mathrm{mo})\end{array}$ \\
\hline 1 & M/62 & Sole & $\begin{array}{l}\text { Cancer } \\
\text { excision }\end{array}$ & $\begin{array}{l}\text { Calcaneus } \\
7 \times 5\end{array}$ & $10 \times 8$ & PTA & None & No & Primary repair & None & 3 & 3 & 24 \\
\hline 2 & $\mathrm{M} / 67$ & Sole & Chronic ulcer & $\begin{array}{c}\text { Calcaneus } \\
5 \times 5\end{array}$ & $15 \times 7$ & PTA & None & Yes & Primary repair & None & 3 & 2.67 & 16 \\
\hline 3 & M/56 & $\begin{array}{l}\text { Heel, medial } \\
\text { ankle }\end{array}$ & Trauma & $\begin{array}{c}\text { Calcaneus } \\
4 \times 4\end{array}$ & $12 \times 8$ & PTA & None & No & Primary repair & None & 3 & 2.67 & 14 \\
\hline 4 & $\mathrm{M} / 49$ & $\begin{array}{l}\text { Anterior and } \\
\text { medial ankle }\end{array}$ & $\begin{array}{l}\text { Postburn scar } \\
\text { contracture }\end{array}$ & $\begin{array}{l}\text { Talus } \\
4 \times 4\end{array}$ & $12 \times 6$ & PTA & None & No & Primary repair & None & 2.67 & 1.33 & 9 \\
\hline 5 & $\mathrm{M} / 37$ & $\begin{array}{l}\text { Dorsum } \\
\text { of foot }\end{array}$ & Trauma & $\begin{array}{l}\text { Navicular, } \\
\text { cuneiform bones } \\
5 \times 5 \text {, tendon } \\
\text { exposure }\end{array}$ & $15 \times 10$ & ATA & None & Yes & STSG & None & 2.67 & 2.5 & 31 \\
\hline 6 & $F / 49$ & $\begin{array}{l}\text { Medial ankle, } \\
\text { sole }\end{array}$ & , Chronic ulcer & $\begin{array}{c}\text { Calcaneus } \\
5 \times 5\end{array}$ & $11 \times 6$ & PTA & None & No & Primary repair & None & 2.5 & 2 & 8 \\
\hline 7 & $\mathrm{M} / 60$ & Anterior tibia & Trauma & $\begin{array}{l}\text { Tibia } 6 \times 5 \text {, } \\
\text { osteomyelitis }\end{array}$ & $12 \times 6$ & ATA & None & No & Primary repair & None & 2.5 & 2.17 & 24 \\
\hline 8 & $\mathrm{M} / 58$ & Anterior tibia & Trauma & Tibia 7×4 & $11 \times 5$ & ATA & None & No & Primary repair & None & 2.84 & 2.5 & 15 \\
\hline 9 & M/68 & $\begin{array}{l}\text { Dorsum } \\
\text { of foot }\end{array}$ & Trauma & $\begin{array}{l}\text { Metatarsal bone } \\
7 \times 7 \text {, tendon } \\
\text { exposure }\end{array}$ & $16 \times 12$ & ATA & None & No & STSG & $\begin{array}{l}\text { Partial loss } \\
(10 \times 2 \mathrm{~cm})\end{array}$ & 2.84 & 2.5 & 12 \\
\hline 10 & M/62 & Sole & $\begin{array}{l}\text { Cancer } \\
\text { excision }\end{array}$ & $\begin{array}{c}\text { Calcaneus } \\
7 \times 7\end{array}$ & $12 \times 8$ & PTA & None & No & Primary repair & None & 2.84 & 2.33 & 26 \\
\hline 11 & M/35 & 1st toe & Trauma & $\begin{array}{l}\text { 1st toe proximal } \\
\text { phalanx } 1 \times 1\end{array}$ & $15 \times 5$ & ATA & None & No & Primary repair & None & 1.34 & 2.5 & 2 \\
\hline 12 & $M / 14$ & Anterior tibia & Trauma & Tibia $6 \times 5$ & $24 \times 8$ & PTA & None & No & Primary repair & None & 2.67 & 2.17 & 3 \\
\hline Mean & 51.42 & & & & & & 0 & & & & 2.65 & 2.36 & 15.3 \\
\hline Rate (\%) & & & & & & & & $16.67 \%$ & $16.67 \%$ & $8.33 \%$ & & & \\
\hline
\end{tabular}

Table 4. Flap survival, debulking procedure, donor site morbidity and outcome scores

\begin{tabular}{|lccl|}
\hline Outcome & $\begin{array}{c}\text { ALT-FC } \\
\text { group } \\
\text { (12 cases) }\end{array}$ & $\begin{array}{c}\text { VL-MC } \\
\text { group } \\
\text { (12 cases) }\end{array}$ & $\begin{array}{c}\text { P- } \\
\text { value }\end{array}$ \\
\hline Flap survival (\%) & 100 & 100 & $0^{\text {a) }}$ \\
Flap complication (\%) & 8.33 & 0 & $0.37^{\text {a) }}$ \\
Debulking procedure (\%) & 16.67 & 16.67 & $0^{\text {a) }}$ \\
Donor site morbidity (5) & 8.33 & 8.33 & $0^{\text {a) }}$ \\
Functional outcomes (0-3) & 2.67 & 2.65 & $0.92^{\text {b) }}$ \\
Cosmetic outcomes (0-3) & 2.4 & 2.36 & $0.95^{\text {b) }}$ \\
\hline ALT-FC, anterolateral fasciocutaneous; VL-MC, vastus lateralis myocu- taneous. \\
a'Chi-square test; bit-test.
\end{tabular}

(75\%) were musculocutaneous perforators. The perforators extend through the septum or the vastus lateralis muscle to supply a large skin flap to the anterolateral aspect of the thigh [13]. In the past, ALT flaps were unusable due to their difficult intramuscular dissection. However, ALT flaps have become a popular flap choice for the reconstruction of soft-tissue defects. Variations in the vascular anatomy of the ALT flap have been classified by the branching patterns of the perforators [11]. The central axis of the flap is indicated by a line drawn from the anterior superior iliac spine to the superolateral border of the patella. The dominant perforators that supply the flap are located within a $3-\mathrm{cm}-$ radius circle at the midpoint of this line [10].

The flap can be harvested as a musculocutaneous flap that includes the vastus lateralis muscle when additional tissue volume is needed. The vastus lateralis muscle has an adequate volume, which can be tailored to fill the defect. When the flap requires part of the muscle, harvesting is easier because intramuscular dissection is not needed, and the twisting of the pedicle is less likely to occur. We used a VL-MC flap when additional volume was needed for weight bearing, such as for the sole or heel pad, or to cover large exposed bone, with positive results. We used a VL-MC flap successfully with good contour and minimal donor site morbidity, enabling patients to achieve good functional outcomes, such as gait function and weight bearing.

Two debulking procedures were needed in patients of both the ALT-FC and VL-MC groups. The patients complained that it was difficult to wear shoes because of the bulky flap, and they were dissatisfied with the flap contour. A sufficient volume of 
the flap was needed to cover the weight-bearing or large, boneexposed area, but the bulkiness of the flap affected ordinary daily functions, such as walking and wearing shoes. After the debulking procedures were performed, all of the patients were satisfied with the functional and cosmetic outcomes of the flaps.

Functional and cosmetic outcomes for both groups were evaluated by two independent physicians and a patient questionnaire. There was no statistical relationship between the mean scores of two groups. These scores are subjective, and the lack of an obvious grading system limits the usefulness of these scores. Further evaluation using objective outcome scoring is needed.

Donor-site defects less than $10 \mathrm{~cm}$ in width are closed directly, while larger defects may require skin grafting. The quadriceps is composed of four muscles: the rectus femoris, the vastus intermedius, the vastus medialis, and the vastus lateralis. The vastus lateralis originates from the greater trochanter, the gluteal tuberosity, and the lateral intermuscular septum. It ends in the patellar ligament with other muscles of the quadriceps femoris. It aids in the extension of the leg. The descending branch of lateral circumflex femoral artery, transverse and ascending branches, and superior genicular lateral artery of the popliteal artery are the blood supply of this muscle. The dominant pedicle is the descending branch of the lateral circumflex femoral artery, and the mean diameter of the artery was found to be $2.1 \mathrm{~mm}$ [14]. It can be used as a muscular and a musculocutaneous flap.

The rectus abdominis flap provides an excellent pedicle caliber, a large muscle volume, and simultaneous flap harvest. However, the rectus abdomins flap has a short pedicle length, and abdominal hernia can occur. The latissimus dorsi flap also provides muscle volume and a consistent, long pedicle; however, it requires intraoperative repositioning. The VL-MC flap has a large caliber pedicle with consistent anatomy, which allows a simple dissection from the lateral thigh. The pedicle can be up to $20 \mathrm{~cm}$ in length, facilitating anastomosis outside of the zone of injury. The vastus lateralis muscle has adequate volume to fill the large dead space. The VL-MC flap does not require positional changes during surgery, and simultaneous flap elevation is possible during the recipient site operation [15]. In defects of the lower extremity, surgery can be performed under epidural anesthesia if the patient cannot tolerate general anesthesia [16].

Because the vastus lateralis is the largest of the quadriceps femoris muscles, the stability of the lateral patella can be affected if vastus lateralis function is impaired. Kuo et al. [13] used a kinetic communicator to assess the isokinetic and isometric strength of the thigh and showed no significant differences in the donorto-normal thigh ratio. Further evaluation of gait function can be performed by the subjective questioning of patients and the use of objective measurements, such as thigh strength.
The ALT flap serves as an ideal flap choice for lower extremity reconstruction because it has maximal reconstructive capacity and produces minimal donor-site morbidity. With the addition of a small cuff of vastus lateralis muscle, a VL-MC flap can be used to fill occasional dead spaces with a comparable survival rate and minimal donor-site morbidity. Additionally, the VL-MC flap does not need intramuscular dissection and can be elevated easily with fewer myocutaneous perforator injuries.

In this study, we suggest that the VL-MC flap should be considered a therapeutic option with excellent functional and cosmetic results for lower extremity reconstruction.

\section{REFERENCES}

1. Coessens BC, Van Geertruyden JP, Vico PG. Free TRAM flap for lower-extremity reconstruction. J Reconstr Microsurg 1994;10:305-11.

2. Kaplan I, Ada S, Ozerkan F, et al. Reconstruction of soft tissue and bone defects in lower extremity with free flaps. Microsurgery 1998;18:176-81.

3. Gonzalez MH, Tarandy DI, Troy D, et al. Free tissue coverage of chronic traumatic wounds of the lower leg. Plast Reconstr Surg 2002;109:592-600.

4. Pu LL, Medalie DA, Lawrence SJ, et al. Reconstruction of through-and-through gunshot wounds to the feet with free gracilis muscle flaps. Ann Plast Surg 2003;50:286-91.

5. Song YG, Chen GZ, Song YL. The free thigh flap: a new free flap concept based on the septocutaneous artery. Br J Plast Surg 1984;37:149-59.

6. Wei FC, Jain V, Celik N, et al. Have we found an ideal softtissue flap? An experience with 672 anterolateral thigh flaps. Plast Reconstr Surg 2002;109:2219-26.

7. Kimura N, Satoh K, Hasumi T, et al. Clinical application of the free thin anterolateral thigh flap in 31 consecutive patients. Plast Reconstr Surg 2001;108:1197-208.

8. Rajacic N, Gang RK, Krishnan J, et al. Thin anterolateral thigh free flap. Ann Plast Surg 2002;48:252-7.

9. Reddy V, Stevenson TR. MOC-PS(SM) CME article: lower extremity reconstruction. Plast Reconstr Surg 2008;121:1-7.

10. Ozkan O, Coskunfirat OK, Ozgentas HE. The use of free anterolateral thigh flap for reconstructing soft tissue defects of the lower extremities. Ann Plast Surg 2004;53:455-61.

11. Kimata $Y$, Uchiyama K, Ebihara S, et al. Anatomic variations and technical problems of the anterolateral thigh flap: a report of 74 cases. Plast Reconstr Surg 1998;102:1517-23.

12. Choi SW, Park JY, Hur MS, et al. An anatomic assessment on perforators of the lateral circumflex femoral artery for anterolateral thigh flap. J Craniofac Surg 2007; 18:866-71. 
13. Kuo YR, Jeng SF, Kuo MH, et al. Free anterolateral thigh flap for extremity reconstruction: clinical experience and functional assessment of donor site. Plast Reconstr Surg 2001;107:1766-71.

14. Tayfur V, Magden O, Edizer M, et al. Anatomy of vastus lateralis muscle flap. J Craniofac Surg 2010;21:1951-3.
15. Nelson JA, Serletti JM, Wu LC. The vastus lateralis muscle flap in head and neck reconstruction: an alternative flap for soft tissue defects. Ann Plast Surg 2010;64:28-30.

16. Yildirim S, Gideroglu K, Akoz T. Anterolateral thigh flap: ideal free flap choice for lower extremity soft-tissue reconstruction. J Reconstr Microsurg 2003;19:225-33. 